Japan. J. Breed. $41: 359 \sim 363$ (1991)

\title{
Short Commuication
}

Spikelet sterility in $F_{1}$ Hybrids between Rice Varieties Silewah and Hayakogane

\author{
Masahiko Maekawa ${ }^{1)}$, Tsuyoshi InukaI $^{1)}$ and Noboru Shrnbashi ${ }^{2)}$ \\ 1) Agricultural Experiment Farm, Faculty of Agriculture, Hokkaido \\ University, Sapporo, 060 \\ 2) Hokkaido Green-Bio Institute, Naganuma, 069-13
}

\begin{abstract}
In order to analyze the cause of the highly spikelet sterility observed in the $\mathrm{F}_{1}$ hybrids between Silewah and Hayakogane, reciprocal crosses between Hayakogane and Silewah were conducted. Since $F_{1}$ hybrids in the reciprocal crosses showed similarly low spikelet fertility, the spikelet sterility in the $F_{1}$ hybrids was not caused by cytoplasmic male sterility. In addition, the $F_{1}$ hybrids displayed normal pollen fertility and crossed seed fertility in reciprocal crosses between $\mathrm{F}_{1}$ hybrids, Silewah/Hayakogane and Hayakogane was normal. These results indicated that pollen and ovule of the $F_{1}$ hybrid were normal. The $F_{1}$ hybrids between Silewah and Hayakogane showed a large number of indehiscent anthers. Accordingly, it was deduced that the highly spikelet sterility in the $F_{1}$ hybrids between Silewah and Hayakogane was mainly caused by indehiscent anthers. When spikelet fertility in the $F_{1}$ hybrids between pedigrees of Hayakogane and Silewah was examined, the $F_{1}$ hybrid between Norin 15 and Silewah showed the same extremely low spikelet fertility as that of the $F_{1}$ hybrid between Silewah and Hayakogane. Furthermore, the $F_{1}$ hybrids between either Kyowa or Hokuto and Silewah were partially fertile. The slightly decreased fertility was also observed in the $F_{1}$ hybrids between either Hashiribozu or Matsumotomochi. These $F_{1}$ hybrids had normal pollen fertility and a number of indehiscent anthers. The $F_{1}$ hybrids of the remaining pedigrees of Hayakogane crossed with Silewah showed a normal spikelet fertility in $\mathrm{F}_{1}$ hybrids crossed with Silewah. These results suggest that varietal differentiation for spikelet sterility in the $F_{1}$ hybrids including Silewah may occur in Japonica rice varieties.
\end{abstract}

KEY WORDS: Oryza sativa, indehiscent anther, indica/japonica hybrid, pollen, spikelet sterility.

\section{Introduction}

Silewah, an Indonesian native rice variety, is extremely cold-resistant and is compatible with Japonica varieties (SATAKe and Toriyama, 1979). Therefore, as a useful gene source for coldresistance at the booting stage, Silewah has been used for improvement of cold-resistance in Hokkaido rice varieties (ABE et al., 1989). However, $F_{1}$ hybrids between Silewah and Hayakogane, a Hokkaido variety showed extremely low spikelet fertility.

This study aimed at analyzing the cause of the very low spikelet fertility in the $F_{1}$ hybrids between Silewah and Hayakogane, and to surveying Hokkaido varieties which showed a similar spikelet sterility in $F_{1}$ hybrids including Silewah to that of the $F_{1}$ hybrid between Silewah and Hayakogane.

\section{Materials and Methods}

Hybrids between Silewah, an Javanica type (Saruyama and Shinbashr, 1990) and Leng

Received January 25, 1991 
Kwang, an Indica type (Satake and Toriyama, 1979) were grown in 1985 while Ishikari, Hayakogane, Silewah, Leng Kwang and $F_{1}$ hybrids between parental strains were raised in 1987. In addition, Hayakogane, pedigrees of Hayakogane, Silewah and $F_{1}$ hybrids between Silewah and pedigrees of Hayakogane including Hayakogane were cultivated in 1989. Four plants were transplanted in a 3 litre pot in the green house. Five immature flowers were expected to open in the next day were collected from each parent and $F_{1}$ hybrid in the summer. The pollen grains were stained with a pottasium iodide solution (I-KI). Spikelet fertility was expressed as the percentage of number of fertile spikelets to total number of spikelets of five panicles.

\section{Results and Discussion}

Spikelet and pollen fertility of $F_{1}$ hybrids in diallel crosses among Hayakogane, Ishikari, Silewah and Leng Kwang was presented in Table 1, except for Leng Kwang/Hayakogane and Leng Kwang/Silewah and pollen fertility of Silewah/Leng Kwang. The very low spikelet fertility of the $F_{1}$ hybrids in reciprocal crosses between Silewah and Hayakogane suggested that the spikelet fertility was under genic and not under cytoplasmic control. $F_{1}$ hybrids in reciprocal crosses between Silewah and Ishikari displayed a normal spikelet fertility, whereas the $F_{1}$ hybrids between Leng Kwang and either Hayakogane or Ishikari showed an almost complete sterility with low pollen fertility. The spikelet fertility of $F_{1}$ hybrids between Silewah and Leng Kwang was partial. On the basis of these results, it is suggested that the genic constitution for spikelet sterility in the $F_{1}$ hybrids between Leng Kwang and either Hayakogane or Ishikari may not be different, but that Hayakogane harbours specific gene(s) for spikelet sterility in the $F_{1}$ hybrids with Silewah in contrast to Ishikari.

Pollen fertility in the $F_{1}$ hybrids between Silewah and either Hayakogane or Ishikari was

Table 1. Spikelet and pollen fertility of parental strains and $F_{1}$ hybrids

\begin{tabular}{llccc}
\hline \hline & & \multicolumn{3}{c}{ Male } \\
\cline { 2 - 5 } Female & Hayakogane & Ishikari & Silewah & Leng Kwang \\
\hline Hayakogane & $87.4 \pm 3.7^{1) \mathrm{a}}$ & $88.3 \pm 9.8$ & $8.5 \pm 2.3$ & $1.2 \pm 1.5$ \\
& $95.1 \pm 1.0^{2) \mathrm{a}}$ & $96.0 \pm 2.8$ & $95.4 \pm 1.8$ & $10.0 \pm 1.7$ \\
Ishikari & $93.8 \pm 7.0$ & $86.2 \pm 2.7^{\mathrm{a}}$ & $85.1 \pm 3.4$ & $0.7 \pm 0.8$ \\
& $95.5 \pm 1.4$ & $91.9 \pm 1.8^{\mathrm{a}}$ & $95.5 \pm 2.0$ & $8.6 \pm 3.8$ \\
Silewah & $11.8 \pm 4.1$ & $80.1 \pm 1.5$ & $84.5 \pm 5.0^{\mathrm{a}}$ & $43.0 \pm 5.2^{\mathrm{b}}$ \\
& $94.5 \pm 1.1$ & $91.9 \pm 1.5$ & $95.1 \pm 3.1^{\mathrm{a}}$ & - \\
Leng Kwang & - & 0.0 & - & $77.0 \pm 5.4^{\mathrm{a}}$ \\
& & $7.5 \pm 3.3$ & & $95.5 \pm 1.1^{\mathrm{a}}$ \\
\hline
\end{tabular}

1); Spikelet fertility. 2); Pollen fertility

a; Selfed.

b; Tested in 1985.

-; Not tested. 
as normal as that of the parents. Furthermore, crossing rates in reciprocal crosses between Hayakogane/Silewah hybrids and Hayakogane were $83.1 \%$ and $83.9 \%$, respectively. The $\mathrm{F}_{1}$ hybrids between Silewah and Hayakogane showed a large number of indehiscent anthers, as presented in Fig. 1. However, several anthers of the hybrids were dehiscent. These results indicated that the spikelet sterility in the $F_{1}$ hybrids between Silewah and Hayakobane is caused not by pollen or ovule sterility. Accordingly, it is assumed that the spikelet sterility of the $F_{1}$ hybrids between Silewah and Hayakogane may result from a large number of indehiscent anthers.

In order to examine whether only $F_{1}$ hybrids between Hayakogane and Silewah showed spikelet sterility or not, the spikelet fertility in the $F_{1}$ hybrids between Silewah and pedigrees of Hayakogane was analyzed. As indicated in Table 2, $F_{1}$ hybrids between Silewah and Norin 15 showed a similar low spikelet sterility to that of the $\mathrm{F}_{1}$ hybrids between Silewah and Hayakogane. The spikelet fertility of the $F_{1}$ hybrids between Silewah and either Hokuto or Kyowa was partial with large variations. Furthermore, the $F_{1}$ hybrids between Silewah and either Matsumotomochi or Hashiribozu displayed a slightly decreased spikelet fertility with moderately large variations, though Hashiribozu showed a slightly low

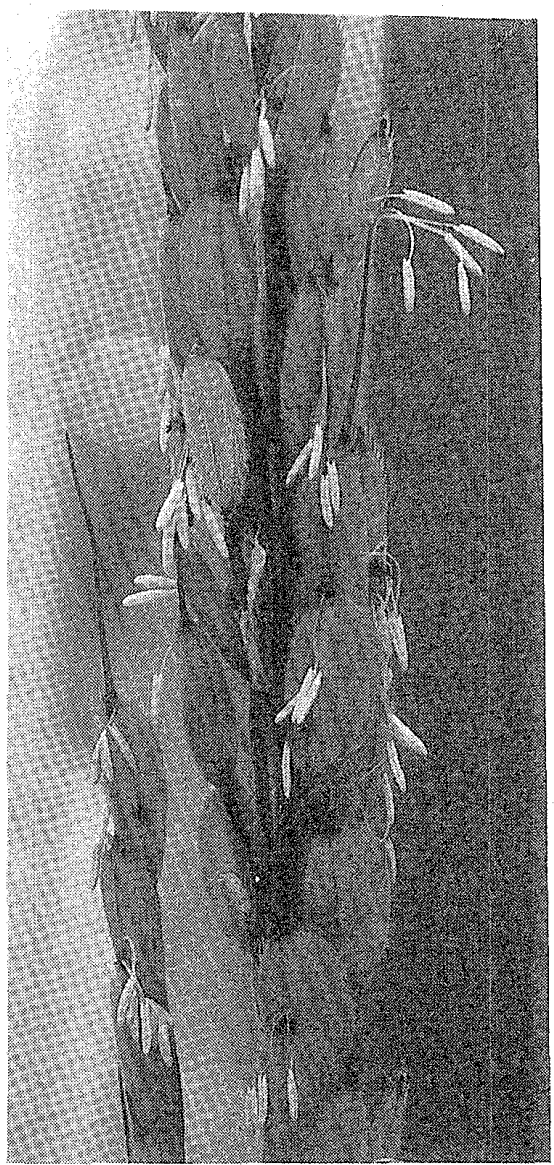

Fig. 1. Anther indehiscence observed in the $F_{1}$ hybrid between Silewah and Hayakogane. spikelet fertility. These $\mathrm{F}_{1}$ hybrids possessed a normal pollen fertility and showed a number of indehiscent anthers. The $F_{1}$ hybrids of the remaining pedigrees of Hayakogane crossed with Silewah showed a normal spikelet fertility. These results indicated that there were varietal differences in the spikelet fertility of the $F_{1}$ hybrids between Silewah and Japonica rice varieties. The relationships between these varieties were as follows; Norin 15 was on the male parental side of Hayakogane, while Hokuto and Kyowa were on the female parental side and Matsumotomochi and Hashiribozu were on the female and male parental sides, respectively. Although the spikelet fertility of $F_{1}$ hybrids between Joiku 272 and Silewah has not been examined yet, the spikelet sterility in the $F_{1}$ hybrids between Silewah and Norin 15 might be caused by the same gene(s) as those between Silewah and Hayakogane. In order to identify the gene(s) for spikelet sterility in these $F_{1}$ hybrids, however, $F_{1}$ hybrids between Hokkaido rice varieties which showed spikelet sterility in the hybrids including Silewah are further needed to be crossed with Silewah. 
Table 2. Spikelet and pollen fertility of parental strains and $F_{1}$ hybrids between pedigrees of Hayakogane and Silewah

\begin{tabular}{lcccc}
\hline \multirow{2}{*}{ Parental strain } & $\mathrm{SF}(\%)$ & $\mathrm{PF}(\%)$ & \multicolumn{2}{c}{ Hybrid } \\
\cline { 4 - 4 } Hayakogane & $92.4 \pm 6.9$ & $94.4 \pm 0.2$ & $0.8 \pm 2.6$ & $91.7 \pm 1.3$ \\
Hokuto & $84.7 \pm 9.0$ & $91.5 \pm 4.8$ & $39.4 \pm 27.8$ & $90.3 \pm 6.5$ \\
Kyowa & $84.2 \pm 9.9$ & $96.7 \pm 3.2$ & $41.8 \pm 24.0$ & $91.7 \pm 3.1$ \\
Yuukara & $91.6 \pm 5.5$ & $97.3 \pm 2.0$ & $83.0 \pm 9.0$ & $96.7 \pm 3.2$ \\
Norin 15 & $75.0 \pm 11.5$ & $89.6 \pm 7.5$ & $0.8 \pm 1.8$ & $91.4 \pm 4.6$ \\
Matsumotomochi & $81.4 \pm 4.8$ & $97.5 \pm 0.9$ & $70.9 \pm 13.8$ & $92.9 \pm 4.2$ \\
Joiku 42 & $93.2 \pm 3.8$ & $98.1 \pm 1.7$ & $88.2 \pm 8.1$ & $95.3 \pm 1.3$ \\
Wasefukoku & $78.3 \pm 7.9$ & $95.1 \pm 3.7$ & $86.2 \pm 6.2$ & $92.9 \pm 10.2$ \\
Eiko & $92.8 \pm 4.5$ & $98.6 \pm 1.2$ & $90.1 \pm 7.2$ & $96.1 \pm 4.1$ \\
Hashiribozu & $69.3 \pm 10.4$ & $89.3 \pm 13.5$ & $71.5 \pm 14.2$ & $97.2 \pm 1.8$ \\
Bozu 6 & $82.9 \pm 8.3$ & $90.8 \pm 7.0$ & $90.7 \pm 5.2$ & $98.1 \pm 1.7$ \\
Sakigake & $79.5 \pm 10.4$ & $90.7 \pm 3.7$ & $90.6 \pm 7.0$ & $97.1 \pm 1.6$ \\
Bozu & $82.9 \pm 6.3$ & $95.6 \pm 7.6$ & $84.5 \pm 9.8$ & $97.6 \pm 1.4$ \\
Silewah & $77.2 \pm 8.5$ & $98.1 \pm 1.8$ & & \\
\hline
\end{tabular}

Note. SF and PF mean spikelet fertility and pollen fertility, respectively.

Satake and ToRiyama (1979) reported that Silewah is compatible with Japonica. On the other hand, IKeHashi and ARAKi $(1984,1986)$ pointed out that the $F_{1}$ hybrids between Silewah and either Japonica or Indica testers showed a partial fertility, but normal pollen fertility. The results obtained in this study demonstrated well that varietal differentiation for the spikelet sterility in the $F_{1}$ hybrids including Silewah may occur in Japonica rices.

\section{Acknowledgement}

This work was supported in part by Grant-in-Aid for Cooperative Research (No.02304015) from the Ministry of Education, Science and Culture, Japan.

We are grateful to Mr. M. Hrwatari and T. Tsunoda, Agr. Expt. Farm, Hokkaido Univ., for their assistance.

\section{Literature Cited}

Abe, N., S. Kotaka, K. Toriyama and M. Kobayashi 1989. Development of the "Rice Norin-PL 8" with high tolerance to cool temperature at the booting stage. Res. Bull. Hokkaido Agric. Exp. Stn. $152: 9 \sim 17$.

IKEHASHI, H. and H. ARAKI 1984. Varietal screening of compatibility types revealed in $\mathrm{F}_{1}$ fertility of distant crosses in rice. Japan. J. Breed. 34:304 313. 
and 1986. Genetics of $\mathrm{F}_{1}$ sterility in remote crosses of rice. In Rice Genetics, Proc. Intl. Rice Genet. Symp. International Rice Research Institute, Manila, 119 130.

SARUYAMA, H. and N. Shinbashi 1990. Japonica and Indica specific rice seed embryo proteins and their utilization for ecospecies classification. Japan. J. Breed. 40(Suppl. 2) : 488 489.

SAtake, T. and K. Toriyama 1979. Two extremely cool-tolerant varieties. Int. Rice Res. Newslett. $4: 9 \sim 10$.

\author{
イネ品種シレワーとはやこがねとの F 雑種に見出された種子不稔 \\ 前川雅彦1)・犬飼 剛1)・新橋 登2) \\ (1) 北海道大学農学部附属農場, 札幌市, $干 060$ ) \\ (2)北海道グリーンバイオ研究所，長潧町，干069-13)
}

インドネシア在来イネ品種シレワーと北海道品種はやこがねとの $\mathrm{F}_{1}$ 雑種で極端な種子不稔が見出された。この 種子不稔の原因について検討したところ，まず細胞質の影響はなく，また $\mathrm{F}_{1}$ 雑種の花粉稔性は正常であった。そ こで， $F_{1}$ 雑種の開花時の葯を観祭したところ，不裂開葯が多数見出された．これらのことから， $\mathrm{F}_{1}$ 雑種の種子稔 性が低い原因は，多数の葯の不裂開に起因しているのではないかと推祭された。そこで，はやこがねとシレワーと の $F_{1}$ 雑種と同様にシレワーとの $\mathrm{F}_{1}$ 雑種が種子不稔を示す品種が他にあるかどうかを明らかにするために，はやこ がるの親系統とシレワーとの間で交雑を行った。その結果，農林 15 号，北斗抢よび共和との $\mathrm{F}_{1}$ 雑種が種子不稔を 示した. 従って，シレワーとの $\mathrm{F}_{1}$ 雑種で種子不稔を生ずる品種が日本型イネ内に分化していることが示唆された. 